\title{
Level of Anxiety and Depression among Postgraduate
}

\section{Psychology Students}

\author{
Taniya Ahuja ${ }^{1}$, Dr.Arun Kumar ${ }^{2}$
}

\section{ABSTRACT:}

The authors examine the level of Anxiety and Depression among Postgraduate Psychology Students. The study was conducted using Hamilton Anxiety Scale in Clinical Evaluation (HAM - A) and Beck Depression Inventory (BDI). The results elicit that the level of Anxiety is high as compared with the level of Depression. Among Social Drinkers, the level of Depression was found to be high and among Non - Social Drinkers the level of Anxiety was found to be high. The results elicits a significant positive correlation between Anxiety and Depression. From the HAM - A tool, the domains of Anxiety were also studied, viz., Psychic Anxiety and Somatic Anxiety, which infers in the study that the level of Psychic Anxiety is high as compared to Somatic Anxiety in both the groups.

Keywords: Anxiety, Depression, Social Drinkers

\section{INTRODUCTION:}

The relation between Anxiety and Depression, long the concept of controversy among clinicians, researchers and theorists, has come the subject of renewed interest. Therefore, a review of the relationship of Anxiety and Depression is timely from several points of view - theoretical, diagnostic and therapeutic.

Anxiety: is most generally, a vague, unpleasant emotional state with qualities of apprehension, dread, distress and uneasiness. Everyone experiences Anxiety. It is characterized most commonly as a diffuse, unpleasant, vague sense of apprehension, often accompanied by autonomic symptoms such as headache, palpitations, perspiration, tightness in the chest, mild stomach discomfort, and restlessness indicated by an inability to sit or stand still for long. Anxiety is frequently distinguished from Fear by its being often (usually say some, always insist others) objectless, whereas fear assumes a specific feared object, person or event. In Freudian theory, anxiety is treated as 1 , with the additional assumption that it acts as a signal that psychic danger would result were an unconscious wish to be realized or acted upon.

\footnotetext{
${ }^{1}$ Amity University, Noida

${ }^{2}$ Amity University, Noida
}

(C) 2015 I T Ahuja, A Kumar; licensee IJIP. This is an Open Access Research distributed under the terms of the Creative Commons Attribution License (http://creativecommons.org/licenses/by/2.0), which permits unrestricted use, distribution, and reproduction in any Medium, provided the original work is properly cited. 
Depression: Mood is a pervasive and sustained feeling tone that is experienced internally and the influences a person's behaviour and perception of the world. Affect is the external expression of mood. Mood can be normal, elevated, or depressed. Healthy persons experience a wide range of mood and have an equally large repertoire of affective expressions, they feel in control of their moods and affects. It is the part of experience to feel unhappy at times of adversities. The symptom of depressed moods is a component of many psychiatric syndromes and is also commonly found in certain physical diseases, for example, in infections such as hepatitis and some neurological disorders. The central features of Depression are depressed mood, negative thinking, lack of enjoyment, reduced energy and slowness.

\section{METHODOLOGY}

The data is collected using Hamilton Anxiety Scale (HAM - A) and Beck's Depression Inventory (BDI) on the post - graduate psychology students (female) in the present investigation to study the levels of anxiety and depression.

Operational Definition: Social Drinking refers to casual drinking in a social setting without an intention to get drunk. According to National Institute on Alcohol Abuse and Alcoholism (NIAAA), "low risk" drinking for females consist of no more than 7 drinks per week and no more than 3 drinks per sitting. For males, it consist of no more than 14 drinks per week and no more than 4 drinks per day. When they drink, they are not bad consequences or problem that occur. If they have a drink, they don't have any surprises friends don't complaint about their behaviour. They don't end up with mood swings, and they don't start nasty fights. Usually a social drinker really doesn't think too much about having a drink. Alcohol isn't constantly on their mind, also, they don't end up losing control or have to come up with a limit because it doesn't go any further than having a drink socially once in a while. A unit can be related to everyday measures for it corresponds to half a pint of beer ( $8 \mathrm{~g}$ per pint), one glass of table wine (8g per glass), one conventional glass of sherry or port ( $150 \mathrm{~g}$ per bottle), and one single bar measure of spirit $(8 g-12 g)$.

Sampling: Two group research design and Non - Probability Convenient Sampling method was used over 40 female post-graduate (psychology) students. The sample is divided in two groups i.e., Group A, as Social Drinkers and Group B as Non - Social Drinkers studying the above mentioned two variables, Anxiety and Depression.

The population was collected between 20 and 30 years of age. For the Social Drinkers, it was a compulsion of being drinking over the duration of one year, must have been drinking in social gatherings ( 3 drinks per sitting) and with an intention of not getting drunk.

Student living with single parents or living away from family as paying guest or with any other psychiatric illness or going through any kind of physical illness were excluded from the present study. 
Hypothesis: a) there will be significant difference among Anxiety and Depression in Postgraduate Psychology Students, b) there will be significant correlation between the Anxiety and Depression among Social and Non - Social Drinkers.

Analysis of Data: Appropriate Statistical Technique such as Mean, Standard Deviation, Correlation and $\mathrm{t}-$ tests were used to analyse the data collection, statistical Package, SPSS 17.00 was used for this purpose.

\section{RESULT}

Table I indicates the mean scores of Anxiety and Depression of the total group, 17.0000 and 16.8000 respectively, infer that the level of Depression (12.3500) is higher in the Group A and level of Anxiety (4.7000) is higher in Group B.

Table II infers that Anxiety and Depression have a significant positive correlation.

Table III elicits Correlation between Anxiety and Depression for Group A, viz., Social Drinkers.

Table IV elicits Correlation between Anxiety and Depression for Group B, viz., Non - Social Drinkers.

Table I

\begin{tabular}{|l|l|l|l|l|l|l|}
\hline & GROUP & $\mathrm{N}$ & MEAN & Std. Deviation & $\mathrm{t}-$ value & Sig - (2 tailed) \\
\hline ANXIETY & $\begin{array}{l}\text { Social } \\
\text { Drinkers }\end{array}$ & 20 & 12.3000 & 7.1458 & 4.023 & .000 \\
\cline { 2 - 7 } & $\begin{array}{l}\text { Non - Social } \\
\text { Drinkers }\end{array}$ & 20 & 4.7000 & 4.5085 & & \\
\hline \multirow{2}{*}{$\begin{array}{l}\text { PSYCHIC } \\
\text { ANXIETY }\end{array}$} & $\begin{array}{l}\text { Social } \\
\text { Drinkers }\end{array}$ & 20 & 7.7000 & 3.7148 & 4.492 & .000 \\
\cline { 2 - 8 } & $\begin{array}{l}\text { Non - Social } \\
\text { Drinkers }\end{array}$ & 20 & 3.2000 & 2.5047 & & \\
\hline \multirow{2}{*}{$\begin{array}{l}\text { SOMATIC } \\
\text { ANXIETY }\end{array}$} & $\begin{array}{l}\text { Social } \\
\text { Drinkers }\end{array}$ & 20 & 3.9000 & 4.2907 & 2.332 & .025 \\
\cline { 2 - 8 } & $\begin{array}{l}\text { Non - Social } \\
\text { Drinkers }\end{array}$ & 20 & 1.4000 & 2.1374 & & \\
\hline \multirow{2}{*}{ DEPRESSION } & $\begin{array}{l}\text { Social } \\
\text { Drinkers }\end{array}$ & 20 & 12.3500 & 7.1398 & 4.125 & .000 \\
\cline { 2 - 7 } & $\begin{array}{l}\text { Non - Social } \\
\text { Drinkers }\end{array}$ & 20 & 4.4500 & 4.7292 & & \\
\hline
\end{tabular}


Level of Anxiety and Depression among Postgraduate Psychology Students

Table II

\begin{tabular}{|c|c|c|c|c|c|}
\hline \multirow{4}{*}{ ANXIETY } & & ANXIETY & SOMATIC & PSYCHIC & DEPRESSION \\
\hline & $\begin{array}{l}\text { Pearson } \\
\text { Correlation }\end{array}$ & 1.000 & $.916(* * *)$ & $.897(* * *)$ & $.659(* * *)$ \\
\hline & Sig. $(2-$ tailed $)$ & . & .000 & .000 & .000 \\
\hline & $\mathrm{N}$ & 40 & 40 & 40 & 40 \\
\hline \multirow[t]{3}{*}{ PSYCHIC } & $\begin{array}{l}\text { Pearson } \\
\text { Correlation } \\
\end{array}$ & $.916(* * *)$ & 1.000 & $.666(* * *)$ & $.648(* * *)$ \\
\hline & Sig. $(2-$ tailed $)$ & .000 & . & .000 & .000 \\
\hline & $\mathrm{N}$ & 40 & 40 & 40 & 40 \\
\hline \multirow[t]{3}{*}{ SOMATIC } & $\begin{array}{l}\text { Pearson } \\
\text { Correlation }\end{array}$ & $.897(* * *)$ & $.666(* * *)$ & 1.000 & $.521(* * *)$ \\
\hline & Sig. $(2-$ tailed $)$ & .000 & .000 & . & .001 \\
\hline & $\mathrm{N}$ & 40 & 40 & 40 & 40 \\
\hline \multirow[t]{3}{*}{ DEPRESSION } & $\begin{array}{l}\text { Pearson } \\
\text { Correlation }\end{array}$ & $.659(* * *)$ & $.648(* * *)$ & $.521(* * *)$ & 1.000 \\
\hline & Sig. $(2-$ tailed $)$ & .000 & .000 & .001 & . \\
\hline & $\mathrm{N}$ & 40 & 40 & 40 & 40 \\
\hline
\end{tabular}

Table III

\begin{tabular}{|c|c|c|c|c|c|}
\hline \multirow{4}{*}{ ANXIETY } & & ANXIETY & SOMATIC & PSYCHIC & DEPRESSION \\
\hline & $\begin{array}{l}\text { Pearson } \\
\text { Correlation }\end{array}$ & 1.000 & $.852(* * *)$ & $.895(* * *)$ & $.510(* * *)$ \\
\hline & Sig. $(2-$ tailed $)$ & & .000 & .000 & .022 \\
\hline & $\mathrm{N}$ & 20 & 20 & 20 & 20 \\
\hline \multirow[t]{3}{*}{ PSYCHIC } & $\begin{array}{l}\text { Pearson } \\
\text { Correlation }\end{array}$ & $.852(* * *)$ & 1.000 & $.566(* * *)$ & $.389(* * *)$ \\
\hline & Sig. $(2-$ tailed $)$ & .000 & & .009 & .090 \\
\hline & $\mathrm{N}$ & 20 & 20 & 20 & 20 \\
\hline \multirow[t]{3}{*}{ SOMATIC } & $\begin{array}{l}\text { Pearson } \\
\text { Correlation }\end{array}$ & $.895(* * *)$ & $.566(* * *)$ & 1.000 & $.479(* * *)$ \\
\hline & Sig. $(2-$ tailed $)$ & .000 & .000 & & .033 \\
\hline & $\mathrm{N}$ & 20 & 20 & 20 & 20 \\
\hline \multirow[t]{3}{*}{ DEPRESSION } & $\begin{array}{l}\text { Pearson } \\
\text { Correlation }\end{array}$ & $.510(* * *)$ & $.389(* * *)$ & $.479(* * *)$ & 1.000 \\
\hline & Sig. $(2-$ tailed $)$ & .022 & .090 & .033 & . \\
\hline & $\mathrm{N}$ & 20 & 20 & 20 & 20 \\
\hline
\end{tabular}

(c) The International Journal of Indian Psychology | 124 
Level of Anxiety and Depression among Postgraduate Psychology Students

Table IV

\begin{tabular}{|c|c|c|c|c|c|}
\hline & & ANXIETY & SOMATIC & PSYCHIC & DEPRESSION \\
\hline \multirow[t]{3}{*}{ ANXIETY } & $\begin{array}{l}\text { Pearson } \\
\text { Correlation }\end{array}$ & 1.000 & $.938(* * *)$ & $.925(* * *)$ & $.510(* * *)$ \\
\hline & $\begin{array}{lll}\text { Sig. } & (2 \quad- \\
\text { tailed }) & & \end{array}$ & . & .000 & .000 & .022 \\
\hline & $\mathrm{N}$ & 20 & 20 & 20 & 20 \\
\hline \multirow[t]{3}{*}{ PSYCHIC } & $\begin{array}{l}\text { Pearson } \\
\text { Correlation }\end{array}$ & $.938(* * *)$ & 1.000 & $.741(* * *)$ & $.676(* * *)$ \\
\hline & $\begin{array}{l}\text { Sig. } \\
\text { tailed })\end{array}$ & .000 & . & .000 & .001 \\
\hline & $\mathrm{N}$ & 20 & 20 & 20 & 20 \\
\hline \multirow[t]{3}{*}{ SOMATIC } & $\begin{array}{l}\text { Pearson } \\
\text { Correlation }\end{array}$ & $.9255(* * *)$ & $.741(* * *)$ & 1.000 & .242 \\
\hline & $\begin{array}{lll}\text { Sig. } & (2 & - \\
\text { tailed }) & & \\
\end{array}$ & .000 & .000 & . & .305 \\
\hline & $\mathrm{N}$ & 20 & 20 & 20 & 20 \\
\hline \multirow[t]{3}{*}{ DEPRESSION } & $\begin{array}{l}\text { Pearson } \\
\text { Correlation }\end{array}$ & $.510(* * *)$ & $.676(* * *)$ & $.242(* * *)$ & 1.000 \\
\hline & $\begin{array}{lll}\text { Sig. } & (2 & - \\
\text { tailed }) & & \\
\end{array}$ & .022 & .001 & .305 & . \\
\hline & $\mathrm{N}$ & 20 & 20 & 20 & 20 \\
\hline
\end{tabular}

\section{SUMMARY}

Everyone feels sad or worried from time to time. Unpleasant feelings are a normal part of life. But when Depression and Anxiety interferes with work, play and/or relations, then, it turns important to take significant action over it. Experts estimate that almost a quarter of people in this world will experience significant problems with anxiety at some point of their lives. And between $15-20 \%$ of people will succumb to the average of Depression at one point or another.

The present piece of work has shown significant findings (according to raw scores) which concluded that majority of the students have higher level of Anxiety as compared to Depression, whereas among Social Drinkers, majority of students have higher level of Depression as compared to Anxiety.

HAM - A, in Group A (Social Drinkers) elicited that $5 \%$ of the population faced Severe Anxiety, $26 \%$ of the Strata faced Moderate Anxiety and 68\% of the Sample faced Normal Level of 
Anxiety. Ironically, according to BDI, it was elicited that $5 \%$ of the population faced, Possible Denial of Depression, Faking Good; which infers that students are denying the fact that they are facing difficulty in balancing their emotions with the daily life and are faking to the other people that they are happy with their lives, $20 \%$ face Moderate to Severe Depression, $30 \%$ of them face Mild to Moderate Depression and the rest $45 \%$ experience normal level of mood swings (mood ups and downs).

HAM - A, in Group B (Non - Social Drinkers) elicited that 5\% experienced Mild level of Anxiety and rest $95 \%$ faced Normal level of Anxiety. Ironically, BDI, elicited that $65 \%$ of the population faced Possible Denial of Depression, Faking Good, 25\% experiences normal level of mood swings (moods ups and downs) and rest $10 \%$ of them faced Mild - Moderate Depression.

\section{INTERPRETATION}

Hypothesis a) expected that there will be significant difference among Anxiety and Depression in Postgraduate Female Students; which is supported by both the variables i.e., Anxiety and Depression. Although there is a very minute difference between the two but still it depicts that the level of Anxiety is higher as compared to the level of Depression. Further the level of Anxiety and Depression is checked in two domains, first in Group A (Social Drinkers) and Group B (Non - Social Drinkers). The mean scores of Anxiety and Depression in Group A (Social Drinkers), evidences that the level of Depression is high. The mean scores of Anxiety and Depression in Group B (Non - Social Drinkers), indicates that level of Anxiety is higher. The mean scores of the domains of Anxiety i.e., Psychic Anxiety (mental agitation and psychological distress) and Somatic Anxiety (physiological complaints related to Anxiety) that Psychic Anxiety is high as compared to the Somatic Anxiety.

In Group A (Social Drinkers), the mean scores of the domain of Anxiety viz., Psychic Anxiety and Somatic Anxiety shows that Psychic Anxiety is high as compared to the Somatic Anxiety and same was the result of the Group B (Non - Social Drinkers). A basic reason for the high levels of Psychic Anxiety among postgraduate students could be daily stress like, worries about the career aspects, meeting the deadlines of the college tasks and providing best performance in their clinical practice.

Hypothesis b) expected that there will be correlation between the level of Anxiety and Depression among Social Drinkers and Non - Social Drinkers, where a positive significant correlation was found between the level of Anxiety and Depression. In both the groups, viz., Social Drinkers and Non - Social Drinkers, Anxiety was found to have positive significant correlation with Depression.

\section{IMPLICATIONS}

The present study is a valuable contribution for the female students pursuing psychology. The results of this study have the following implication: 
1. The results indicate that the level of Anxiety and Depression, both act together among Psychology Students. The degree of variation of Anxiety and Depression may be high or low.

2. The raw scores of the study imply for some of the students an urgent call for clinical observation as the test result indicates that they have Severe Depression or Severe Anxiety.

\section{LIMITATIONS}

The present study has the following limitations:

1. Since the sample size is small, reliable generalization cannot be done.

2. Only Psychology students have been included, if students of other fields would have also been considered, findings would have been better.

3. Female students who Smoke have not been included in the study, had this factor included then the level of anxiety and depression would have been more specific.

4. If male students were also included, a comparison between male and female studies could have been made.

\section{REFERENCES}

Beck T, A. (1996) Beck Depression

Burrows G.D. (1977). Handbook of studies

Biomedical Press. New York,
Inventory Manual.

on Depression. North - Holland

Google Books.

Hamilton M. (1959). Hamilton Anxiety Rating Scale.

Sadock B. J, and Sadock V. A. (2007). Synopsis of Psychiatry Behavioural

Science/Clinical Psychiatry. Tenth Edition. Philadelphia. Lippincott Williams \& Wilkins. $579-581,587-588,592-597, \& 624-625$.

Vyas J.N, and Ahuja N. (1999). Textbook of Postgraduate Psychiatry. Second Edition. Vol 1. $249-252 \& 255$. 